\title{
Pengaruh Pemberian Limbah Penetasan Yang Diolah Dengan Mineral Pengikat Bentonit Terhadap Performans Produksi Ayam Kampung Super
}

\author{
B. Sulistiyanto*, S. Sumarsih, C. S. Utama \\ Departemen Peternakan, Fakultas Peternakan dan Pertanian, Universitas Diponegoro, Semarang 50275 \\ Dikirim 29 November 2018; Diterima 07 Februari 2019
}

\begin{abstract}
ABSTRAK
Pengolahan limbah penetasan dengan bentonit menujukkan kelayakan dan keamanan secara kimia maupun mikrobiologisnya sebagai sumber pakan alternatif. Penelitian bertujuan untuk melengkapi dasar kajian pemanfaatan limbah penetasan terolah sebagai bahan pakan alternatif ternak lokal. Penelitian dilaksanakan dengan rancangan acak lengkap pola faktorial $2 \times 4 \times 2$, faktor pertama adalah aras mineral pengikat bentonit 3 dan $4 \%$, level penggunaan limbah penetasan terolah 0,10, 20 dan 30\% sebagai faktor ke dua dan umur ayam 2 dan 4 minggu sebagai faktor ke tiga, masing-masing diulang 3 kali dengan 5 unit percobaan setiap ulangan. Hasil penelitian menunjukkan, penggunaan bentonit $4 \%$ dalam pengolahan limbah penetasan dan aras penggunaan limbah penetasan dalam ransum, tidak berpengaruh nyata terhadap pertumbuhan ayam $(\mathrm{P}>0.05)$. Pengaruh nyata penggunaan bentonit, maupun aras penggunaan limbah penetasan terolah mampak nyata ketika berinteraksi dengan umur ayam $(\mathrm{p}<0.05)$. Rata-rata bobot badan dan pertambahan bobot harian tertinggi pada ransum kontrol pada semua umur, dan terendah pada ransum dengan 30\% limbah penetasan yang diolah dengan bentonit $4 \%$. Hal yang sama diperlihatkan pada nilai konversi pakan, nilai tertinggi dicapai pada ayam umur 4 minggu dengan ransum $30 \%$ limbah penetasan yang diolah dengan bentonit $4 \%$. Disimpulkan bahwa hasil pengolahan limbah penetasan dengan $4 \%$ bentonit layak digunakan pada ayam umur lebih dari 2 minggu, dan penggunaan limbah penetasan terolah dalam ransum tidak lebih dari $20 \%$.
\end{abstract}

Kata Kunci: Bentonit, Limbah penetasan, Perfoman produksi, Ayam

\section{Effect of Administration the Hatchery Wastes Processed with Binders Bentonite on the Production Performances of Crossbreed-Native Chickens}

\begin{abstract}
Study of effect addition of natural bentonite on hatchery wastes processing proven the chemical and microbiological feasibility and safety of the product as an alternative feed source. The aim of experiment is completing the study of the utilization of processed hatchery waste as an alternative to local feedstuffs. The experiment was carried out by a factorialcompletely randomized design of $2 \times 4 \times 2$, the first factor was the level of natural bentonite 3 and $4 \%$, level of the treated hatchery waste products $0,10,20$ and $30 \%$ as the second factor, and the age of chickens 2 and 4 weeks as a third factors, each of treatment was repeated 3 times with 5 experimental units per replications. The result showed that the use of $4 \%$ bentonite in hatchery waste treatment and level of hatchery waste in the diet did not significantly affect the growth of chickens $(P>0.05)$. The significant effect of bentonite, as well as a level of processed hatchery waste in the diet, seem to be evident when those have interacted with chickens age ( $p$ <.05). Average body weight and daily weight gain were highest in control rations at all ages determined and lowest on rations with $30 \%$ hatchery waste treated with $4 \%$ bentonite. The similarity effect was provided to the value of feed conversion. The highest value was achieved in 4 weeks old chickens with $30 \%$ hatchery rations treated with $4 \%$ bentonite. It was concluded that processing hatchery wastes with $4 \%$ bentonite were feasible to be used in chickens that elder than 2 weeks, and the level of hatchery waste product in diets was not more than $20 \%$.
\end{abstract}

Keywords: Bentonite, Hatchery waste, Production perfomances, Chickens

\section{PENDAHULUAN}

Limbah penetasan memiliki kandungan nutrien yang baik, yaitu protein kasar $(33,1 \%)$, lemak kasar $29 \%$, serat kasar $12,1 \%$, energy metabolis $23,9 \mathrm{MJ} / \mathrm{Kg}$, kalsium 25,62\% dan fosfor 1,47\% (Lilburn et al., 1997, Mehdipour et al., 2009). Penelitian pendahuluan kami mencatat bahwa limbah segar industri penetasan yang terdiri dari cangkang telur, telur infertil, telur gagal menetas dan DOC (day old chick) afkir memiliki kandungan air $\pm 60 \%$, protein kasar $\pm 20 \%$ dan lemak kasar $\pm 9 \%$, sehingga menyebabkan limbah penetasan menjadi mudah rusak, busuk dan berbau tidak sedap. Selain itu, limbah penetasan yang terdiri atas cangkang

*Penulis Korespondensi: Bambang Sulistiyanto

Alamat: Jl. Prof. H. Soedarto, S.H., Tembalang Semarang,

50275E-mail: bsoe107@gmail.com telur, telur gagal menetas dan DOC afkir memiliki penampilan yang tidak menyenangkan, sehingga perlu penanganan untuk memperbaiki penampilan fisikorganoleptik, sekaligus memepertahankan komponen nutrisinya sebelum dimanfaatkan sebagai sumber pakan alternatif.

Pengeringan dan pembuatan pellet adalah proses pengolahan yang direkomendasikan efektif untuk memperbaiki penampilan fisik, sekaligus mempertahakan kandungan nutrisi limbah penetasan. Pemanasan dan tekanan pada proses pelleting tidak berpengaruh terhadap ketersediaan asam amino, maupun energi metabolis, dan dapat menurunkan nilai konversi pakan (Serrano et al., 2013; Cerrate et al., 2009; Cutlip et al,. 2008). Pelleting dengan penambahan mineral pengikat terbukti mampu menekan pertumbuhan jamur pada bahan maupun pakan (Tabib et al., 1984), memperbaiki struktur pellet, 
mengikat aflatoksin maupun memperbaiki pemanfaatan nutrisi (Trckova et al., 2004; Corey et al., 2014; Salari et al., 2006; Pasha et al., 2007). Penggunaan bentonit maupun zeolit dalam pengolahan limbah penetasan terbukti mampu memperbaiki penampilan fisik organoleptik dan mikrobioligisnya (Wardana et al., 2016; Nugraha et al., 2016; Sulistiyanto et al., 2016a; Sulistiyanto et al., 2016b). Namun demikian, informasi mengenai penggunaan bentonit dalam pengolahan limbah penetasan dan pengaruhnya terhadap penampilan produksi ternak masih terbatas. Oleh sebab itu, pada penelitian ini dikaji pengaruh penggunaan limbah penetasan yang diolah dengan terhadap penampilan produksi ayam kampung super (ayam kampung persilangan), sebagai dasar pertimbangan pemberdayaan sumberdaya lokal dan kelayakannya sebagai bahan pakan alternatif.

\section{MATERI DAN METODE}

Penelitian dilakukan di laboratorium Tenkologi Pakan, Fakultas Peternakan dan Pertanian, UNDIP.

\section{Materi Penelitian}

Seratus lima puluh ekor DOC ayam kampung "super" unsexed dengan bobot badan awal $34 \pm 4 \mathrm{~g}$ ditempatkan pada kandang batere sesuai dengan perlakuan, yaitu : aras bentonit dalam pembuatan pellet imbah penetasan $(3 \times 4 \%)$, aras limbah penetasan terolah (0, 20, 30 dan 40\%), dan umur ayam 2 dan 4 minggu, masing-masing dengan 3 ulangan, dengan 3 ekor DOC untuk setiap ulangan). Komposisi ransum perlakuan seperti tersaji pada Tabel 1.

Pengolahan limbah penetasan mengacu pada Sulistianto et al.,(2016a). Limbah penetasan yang terdiri cangkang telur (30\%), telur gagal menetas(60\%) dan DOC $(10 \%)$ afkir dihancurkan, selanjutnya ditambah onggok $10 \%(\mathrm{~B} / \mathrm{B})$ dan dicampur rata. Kemudian ditambahkan bentonit sesuai perlakuan, yaitu 3 dan 4\% (B/B) dan dicampur rata. Selanjutnya dilakukan pemanasan pada suhu $80^{\circ} \mathrm{C}$ selama 5 menit dan dicetak menjadi pellet. Pengeringan dilakukan dengan menggunakan pengering aliran udara panas, sampai kadar air $\pm 12 \%$. Pellet limbah penetasan hasil olahan, selanjutnya disimpan dalam kantong plastik dan dibuat tepung untuk dijadikan salah satu komponen penyusun ransum perlakuan $(0,10,20$ dan 30\%).

\section{Metode Penelitian}

Penelitian dilakukan dengan menggunakan rancangan acak lengkap pola faktorial $2 \times 4 \times 2$ dengan ulangan 3 kali dan masing-masing ulangan terdiri atas 3 unit percobaan. Ayam diberikan ransum perlakuan secara ad libitum sampai umur 4 minggu. Bobot badan (BB) setiap periode dihitung berdasarkan hasil penimbangan ayam pada umur 0,2 dan 4 minggu dalam satuan g/ekor. Rata-rata pertambahan bobot badan harian(PBBH) dihitung dengan menghitung selisih bobot akhir dan sebelumnya dibagi jumlah hari dalam satuan g/ekor/hari. Konsumsi pakan (KP) harian dihitung dengan jumlah pakan yang diberikan dikurangi dengan sisa pakan yang diberikan setiap harinya dalam satuan g/ekor. Konversi pakan dihitung dari rerata konsumsi harian dibagi dengan rerata pertambahan bobot harian. Data dianalisis menggunakan analisis ragam untuk melihat pengaruh perlakuan (Steel dan Torrie, 1989).

\section{HASIL DAN PEMBAHASAN}

\section{Hasil Penelitian}

Tabel 2 memperlihatkan pengaruh perlakuan terhadap bobot badan, konsumsi pakan harian, pertambahan bobot badan harian dan konversi pakan. Bobot badan ayam kampung super, secara parsial tidak dipengaruhi oleh penggunaan bentonit 3 dan $4 \%$ maupun aras penggunaan limbah penetasan terolah $(\mathrm{P}>0,05)$, tetapi secara parsial dipengaruhi oleh umur ayam, maupun interaktif umur dan aras limbah penetasan terolah, serta aras bentonit dalam pengolahan $(\mathrm{P}<0,05)$. Bobot badan ayam menurun dengan meningkatnya tingkat penggunaan bentonit dan aras limbah penetasan terolah, serta berkurangya umur ayam.

Tabel 1. Komposisi ransum perlakuan pengaruh aras penggunaan limbah penetasan terolah dengan penambahan Bentonite

\begin{tabular}{lcccccccc}
\hline \hline & \multicolumn{4}{c}{$\mathrm{A} 1$} & \multicolumn{4}{c}{$\mathrm{A} 2$} \\
\cline { 2 - 8 } & $\mathrm{B} 0$ & $\mathrm{~B} 1$ & $\mathrm{~B} 2$ & $\mathrm{~B} 3$ & $\mathrm{~B} 0$ & $\mathrm{~B} 1$ & $\mathrm{~B} 2$ & $\mathrm{~B} 3$ \\
\hline Pakan komersial & 37.5 & 37.5 & 37.5 & 37.5 & 37.5 & 37.5 & 37.5 & 37.5 \\
Jagung & 30 & 25 & 20 & 10 & 30 & 25 & 20 & 10 \\
Bungkil Kedele & 30 & 25 & 20 & 10 & 30 & 25 & 20 & 10 \\
Limbah penetasan terolah & 0 & 10 & 20 & 30 & 0 & 10 & 20 & 30 \\
Minyak kelapa & 2 & 2 & 2 & 2 & 2 & 2 & 2 & 2 \\
Mineral mix & 0,5 & 0,5 & 0,5 & 0,5 & 0,5 & 0,5 & 0,5 & 0,5 \\
ME (kkal/kg) & 2995,6 & 3005,9 & 2990,9 & 2998,5 & 2997,6 & 2990,0 & 2986,8 & 2991,6 \\
CP (\%) & 22,9 & 23,0 & 22,9 & 23,0 & 22,8 & 22,9 & 23,0 & 23,0 \\
Rasio ME/CP & 131 & 131 & 130 & 130 & 131 & 131 & 130 & 130 \\
\hline A: & & & & & & &
\end{tabular}

A : aras bentonite dalam pengolahan limbah penetasan (3 dan $4 \%$ )

$\mathrm{B}$ : aras penambahan limbah penetasan terolah dalam ransum $(0,10,20$ dan $30 \%)$ 
Tabel 2. Pengaruh perlakuan penggunaan bentonit (A), aras limbah penetasan terolah (B) dan Umur Ayam (C) terhadap bobot badan, konsumsi pakan harian, pertambahan bobot badan hariam dan konversi pakan

\begin{tabular}{|c|c|c|c|c|c|c|c|c|c|c|c|c|c|c|c|}
\hline & \multicolumn{4}{|c|}{ A1 } & \multicolumn{4}{|c|}{$\mathrm{A} 2$} & \multicolumn{7}{|c|}{ Signifikansi pengaruh perlakuan } \\
\hline & B0 & B1 & B2 & B3 & B0 & B1 & $\mathrm{B} 2$ & B3 & A & $\mathrm{B}$ & $\mathrm{C}$ & $\mathrm{AB}$ & $\mathrm{AC}$ & $\mathrm{BC}$ & $\mathrm{ABC}$ \\
\hline \multicolumn{16}{|c|}{ Bobot ayam (g/ekor) } \\
\hline $\mathrm{C} 1$ & 189 & 166 & 157 & 157 & 188 & 161 & 153 & 125 & \multirow[b]{2}{*}{ ns } & \multirow[b]{2}{*}{ ns } & \multirow[b]{2}{*}{$\mathrm{s}$} & \multirow[b]{2}{*}{$\mathrm{s}$} & \multirow[b]{2}{*}{$\mathrm{s}$} & \multirow[b]{2}{*}{$\mathrm{s}$} & \multirow[b]{2}{*}{$\mathrm{s}$} \\
\hline $\mathrm{C} 2$ & 379 & 305 & 297 & 292 & 370 & 296 & 294 & 229 & & & & & & & \\
\hline \multicolumn{16}{|c|}{ Pertambahan bobot badan harian(g/ekor/hari) } \\
\hline $\mathrm{C} 1$ & 10,86 & 9,06 & 8,77 & 8,39 & 8,82 & 8,43 & 6,46 & 8,73 & \multirow{2}{*}{$\mathrm{ns}$} & \multirow{2}{*}{$\mathrm{ns}$} & \multirow{2}{*}{$\mathrm{s}$} & \multirow{2}{*}{ S } & \multirow{2}{*}{$\mathrm{S}$} & \multirow{2}{*}{ S } & \multirow{2}{*}{$\mathrm{s}$} \\
\hline $\mathrm{C} 2$ & 13,36 & 9,98 & 9,82 & 9,90 & 9,78 & 9,90 & 7,27 & 8,50 & & & & & & & \\
\hline \multicolumn{16}{|c|}{ Konsumsi pakan (g/ekor/hari) } \\
\hline $\mathrm{C} 1$ & 23,6 & 19,6 & 20,0 & 18,2 & 20,1 & 19,9 & 18,3 & 17,3 & \multirow[b]{2}{*}{ ns } & \multirow[b]{2}{*}{ ns } & \multirow[b]{2}{*}{$\mathrm{S}$} & \multirow[b]{2}{*}{ ns } & \multirow[b]{2}{*}{$\mathrm{s}$} & \multirow[b]{2}{*}{ S } & \multirow[b]{2}{*}{$\mathrm{s}$} \\
\hline $\mathrm{C} 2$ & 29,2 & 25,3 & 24,1 & 25,5 & 25,7 & 25,7 & 24,6 & 20,4 & & & & & & & \\
\hline \multicolumn{16}{|c|}{ Konversi pakan } \\
\hline $\mathrm{C} 1$ & 2,10 & 2,09 & 2,20 & 2,13 & 1,84 & 2,14 & 2,13 & 2,60 & \multirow[b]{2}{*}{ ns } & \multirow[b]{2}{*}{ ns } & \multirow[b]{2}{*}{$\mathrm{s}$} & \multirow[b]{2}{*}{ S } & \multirow[b]{2}{*}{$\mathrm{s}$} & \multirow[b]{2}{*}{$\mathrm{s}$} & \\
\hline $\mathrm{C} 2$ & 2,27 & 2,45 & 2,37 & 2,49 & 1,95 & 2,54 & 2,41 & 2,71 & & & & & & & S \\
\hline
\end{tabular}

Keterangan :

A : aras bentonit dalam pengolahan limbah penetasan (3 dan $4 \%$ )

$\mathrm{B}:$ aras penambahan limbah penetasan terolah dalam ransum $(0,10,20$ dan $30 \%)$

$\mathrm{C}$ : umur ayam (2 dan 4 minggu)

$\mathrm{AB}, \mathrm{AC}, \mathrm{BC}, \mathrm{ABC}$ : interaksi factor $\mathrm{A}$ dan $\mathrm{B}, \mathrm{A}$ dan $\mathrm{C}, \mathrm{B}$ dan $\mathrm{C}$, serta $\mathrm{A}$ dan $\mathrm{B}$ dan $\mathrm{C}$

Signifikasi pengaruh perlakuan : pengaruh parsial dan atau interaktif perlakuan, ns -Non signifikan, s-signifikan

Pertambahan bobot badan harian tidak dipengaruhi aras penggunaan limbah penetasan terolah, maupun jumlah bentonit yang digunakan dalam pengolahan limbah penetasan $(\mathrm{P}>0,05)$, namun pengaruh nyata nampak signifikan pada interaksinya $(\mathrm{P}<0,05)$. Pengaruh umur secara parsial maupun interaksi dengan perlakuan lain nyata mempengaruhi PBBH. Senada dengan perkembangan bobot badan, PBBH ayam mengalami penurunan dengan peningkatan jumlah bentonit dan aras limbah penetasan terolah, serta berkurangnya umur ayam.

Konsumsi pakan secara signifikan dipengaruhi oleh umur ayam baik secara parsial maupun interaktif dengan faktor lainnya $(\mathrm{P}<0,05)$. Konsumsi pakan meningkat dengan bertambahnya umur ayam dan berkurangya kadar bentonit, maupun jumlah limbah penetasan terolah yang digunakan dalam ransum. Nilai konversai pakan yang secara signifikan dipengaruhi oleh umur ayam baik secara parsial, maupun interaktif dengan faktor lainnya $(\mathrm{P}<0,05)$. Konversi pakan meningkat dengan bertambahnya umur ayam dan meningkatnya kadar bentonit maupun jumlah limbah penetasan terolah yang digunakan dalam ransum.

\section{Pembahasan}

Penggunaan mineral pengikat pada pengolahan limbah penetasan pada penelitian ini memberikan pengaruh yang kurang memuaskan terhadap semua parameter yang diamati, kuhususnya pada ayam periode awal ( $<2$ minggu). Hal ini berbeda dengan apa yang dilaporkan oleh $\mathrm{Hu}$ et al.,(2013) dan Tang et al.,(2015) bahwa pemakaian mineral binders sebagai pengendali mikroflora saluran pencernaan mampu memperbaiki PBBH maupun efisiensi pakan pada broiler umur 1-21 hari. Rendahnya bobot badan inisial dan PBBH, serta rendahnya efisiensi pakan dibandingkan broiler, disebabkan kualitas genetik ayam yang lebih rendah dibanding broiler ((Jaturasitha et al., 2002).

Kecenderungan penurunan tingkat konsumsi pakan pada penelitian ini tidak sejalan dengan penelitian sebelumnya yang menyebutkan bahwa konsumsi ayam meningkat dengan peningkatan konsentrasi bentonit, namun peran umur terhadap konsumsi pakan dalam hal ini sejalan dengan penelitian sebelumnya (Salari et al., 2006 dan Katouli et al., 2010). Pengaruh penggunaan bentonite pada penelitian ini sejalan dengan Damiri et al., (2012), bahwa peningkatan jumlah bentonit dapat menurunkan $\mathrm{PBBH}$ dan meningkatkan konversi pakan pada ayam umur 14 minggu dan pengaruh tersebut berubah dengan bertambahnya umur ayam, yaitu ayam umur lebih dari 4 minggu memberikan respon positif pada peningkatan jumlah bentonit.

Meskipun penampilan produksi ayam lebih rendah dibanding broiler, penampilan produksi ayam kampung super yang dipelihara dengan pakan berbahan limbah penetasan terolah lebih baik dibanding ayam kampung yang diberi pakan komersial. Hasil penelitian ini dibandingkan dengan Jaturasitha et al., (2002) untuk bobot inisial ayam pada umur 2 minggu adalah $162 \mathrm{~g} \underline{v s} 90 \mathrm{~g}$ dan pada umur 4 minggu $308 \mathrm{~g} \underline{v s} 213$ g, untuk PBBH 2 dan 4 minggu adalah 9,23 g/ekor/hari $\underline{v s} 4,24$ g/ekor/hari dan 10,10 g/ekor/hari vs 7,32 g/ekor/hari, sedangkan untuk konversi pakan $2,15 \underline{v s}$ 5,03 dan $2.40 \underline{\text { vs }} 3,03$.

Pengaruh positif penggunaan limbah penetasan yang diolah dengan bentonit, dikarenakan pada proses pengolahan tetapi tidak sampai mengalami kerusakan, sehingga kecernaannya meningkat (Chiu dan Wei, 2011), serta jumlah bentonit yang dipergunakan ada pada jumlah yang aman $(<4,5 \%)$, sehingga tidak mengganggu karakteristik darah maupun penampilan biokimia ternak yang mengkonsumsinya (Safaeikatouli 
et al., 2010). Lebih lanjut bentonit dapat berperan sebagai antimikrobia pada saluran pencernaan ayam, pengikat senyawa beracun, memperbaiki fungsi penyerapan pada usus halus, serta meningkatnya respon kekebalan ayam (Almeida et al., 2014, Agboola et al., 2015, Ezzat et al., 2016). Secara umum hasil penelitian menunjukkan pengolahan limbah penetasan dengan cara pelleting dan dengan penambahan bentonit layak dipergunakan sebagai bahan penyusun ransum dengan beberapa batasan untuk memperoleh hasil yang optimal.

\section{KESIMPULAN}

Disimpulkan bahwa pemberian limbah penetasan yang diolah dengan bentonit sampai $4 \%$ pada ayam kampung super layak digunakan sebagai bahan pakan alternatif untuk ayam kampung super yang berumur umur lebih dari 2 minggu dengan tingkat penggunaan $20 \%$.

\section{UCAPAN TERIMA KASIH}

Penulis sangat berterima kasih kepada Universitas Diponegoro atas dukungan keuangan melalui DIPA-UNDIP Nomor Kontrak: SP DIPA042.01.2.400898/2016, dan juga kepada segenap tim panelis dan teknisi atas dukungan yang telah diberikan dalam pelaksanaan pekerjaan laboratorium.

\section{DAFTAR PUSTAKA}

Agboola A. F., B. R. O. Omidiwura, O. Odu, F. T. Odupitan, and E. A. Iyayi. 2015. Effect of probiotic and toxin Binder on performance, intestinal microbiota and gut morphology in Broiler Chickens. Journal Animal Science Advance 5(7): 1369-1379.

Almeida, J. A. S., N. P. Ponnuraj, J. J. Lee, P. Utterback, H. R. Gaskins, R. N. Dilger, and J. E. Pettigrew. 2014. Effects of dietary clays on performance and intestinal mucus barrier of broiler chicks challenged with Salmonella enterica serovar Typhimurium and on goblet cell function in vitro. Poultry Science 93: 839847.

Cerrate, S., S. Wang, Coto, F. Yan and P. W. Waldroup. 2009. Effect of pellet diameter in broiler starter diets on subsequent performance. Journal Applied Poultry Research 18: 590-597.

Chiu, W. Z. and H. W. Wei. 2011. Optimization of the thermal conditions for processing hatchery waste eggs as meal for feed. Poultry Science 90: 1080-1087.

Corey, A. M., K. G. S. Wamsley, T. S. Winowiski and J. S. Moritz. 2014. Effects of calcium lignosulfonate, mixer-added fat,and feed form on feed manufacture and broiler performance. Journal Applied Poultry Research 23: 418-428.

Cutlip, S. E., J. M., Hott, N. P. Buchanan, A. L. Rack, J, D. Latshaw and J. S. Moritz, 2008. The effect of steam-conditioning practices on pellet quality and growing broiler nutritional value. Journal Applied Poultry Research 17 (2): 249-261.

Damiri, H., M. Chaji, M. Bojarpour and M. Mamuei. 2012. Effect of different sodium bentonite levels on performance, carcass traits and passage rate of broilers. Pakistan Veterinary Journal 32(2): 197-200.

Ezzat, W., A. E. El-Slamony, A. M. Rizk, I. A. Fathey, and M. M. Sabry. 2016. Effect of supplementing diet with sodium bentonite and/or organic chromium on productive, physiological performance and immune response of matrouh chickens strain during growth period. Egypt Poultry Science 36(3): 841-857.

Hu, C. H., Z. C. Qian, J. Song, Z. S. Luan and A. Y. Zuo. 2013. Effects of zinc oxidemontmorillonite hybrid on growth performance, intestinal structure, and function of broiler chicken. Poultry Science $92: 143-150$

Jaturasitha, S., V. Leangwunta, A. Leotaragul, A. Phongphaew, T. Apichartsrungkoon, N. Simasathitkul, T. Vearasilp, L. Worachai and U. Meulen. 2002. A comparative study of Thai native chicken and broiler on productive performance, carcass and meat quality. Deutscher Tropentag 2002. Conference on International Agricultural Research for Development. Witzenhausen, October 9-11, 2002.

Lilburn, M.S., G. W. Barbour, R. Nemasetoni, C. Coy, M. Werling and A. G. Yersin. 1997. Protein quality and calcium availability from extruded and autoclaved turkey hatchery residue. Poultry Science 76: 841-848.

Mehdipour, M., M. S. Shargh, B. Dastar and S. Hassani, S. 2009. Effects of different levels of hatchery wastes on the performance, carcass and tibia ash and some blood parameters in broiler chicks. Pakistan Journal of Biologycal Science 12: 1272-1276.

Nugroho A. A., S. Sumarsih, dan B. Sulistiyanto. 2016. Kandungan Total Bakteri Dan Total Fungi Pellet Limbah Penetasan Yang Dibuat Dengan Penambahan Bentonit. Jurnal Agripet 16 (2): 69-75.

Pasha, T. N., M. U. Farooq, F. M. Khattak, M. A. Jabbar and A. D. Khan. 2007. Effectiveness of sodium bentonite and two commercial products as aflatoxin absorbents in diets for broiler chickens. Animal Feed Science and Technology $132: 103-110$

Safaeikatouli, M., Y. Jafariahangari and A. Baharlouei. 2010. Effects of dietary inclusion of sodium bentonite on biochemical characteristics of 
blood serum in broiler chickens. International Journal of Agriculture and Biology 12: 877-880

Salari, S., H. Kermanshahi and H. N Moghaddam. 2006. Effect of sodium bentonite and comparison of pellet vs mash on performance of broiler chikens. International Journal of Poultry Science 5(1): 31-34

Serrano, M. P., M. Frikha, J. Corchero and G. G. Mateo. 2013. Influence of feed form and source of soybean meal on growth performance, nutrient retention, and digestive organ size of broilers. 2 . Battery study. Poultry Sci. 92 (3): 693-708.

Steel, R. G. D. dan J. H. Torrie. 1989. Prinsip dan Pprosedur Satistika Suatu Pendekatan Biometric. Alih bahasa B Sumantri. Penerbit PT Gramedia. Jakarta.

Sulistiyanto, B., C. S. Utama, dan S. Sumarsih. 2016a. Effect of adminiterin Zeolit on the physical performance of the pellet product of the chickens hatchery wastes. Proceedings of International Seminar On Livestock Production and Veterinary Technology, Bali, 10-12 $2^{\text {th }}$ August 2016. p 415-421

Sulistiyanto, B., S. Sumarsih dan C. S. Utama. 2016b. Kualitas fisik-organoleptik pellet limbah penetasan sebaai bahan pakan alternatif pada level penambahan bentonit yang berbeda. Prosiding Seminar Nasional, Pengembangan Peternakan Berkelanjutan ke-8, Pengembangan Sumbedaya Ternak Lokal dalam Pencapaian Sustainable Development Goals. Jatinangor, $16^{\text {th }}$ Nopember 2016. p 125-129

Tang, Z.G., G. Y. Chen, L. F. Li, C. Wen, T. Wang and Y. M. Zhou. 2015. Effect of zinc-bearing zeolite clinoptilolite on growth performance, zinc accumulation, and gene expression of zinc transporters in broilers. Journal of Animal Science 93: 620-626

Trckova, M., L. Matlova, L. Dvorska and Pavlik, I. 2004. Kaolin, bentonite, and zeolites as feed supplements for animals: health advantages and risks. Veterinary Medicine Czech 49 (10): 389399.

Wardana B. A., B. Sulistiyanto, dan S. Sumarsih. 2016. Pengaruh penambahan zeolit pada proses pelletizing limbah penetasan terhadap kandungan Coliform dan Salmonella produk pellet. Jurnal Agripet 16(1):42-48. 